UDC 811.111'42:808.51

DOI https://doi.org/10.32838/2710-4656/2021.4-1/16

Biletska I. $O$.

Pavlo Tychyna Uman State Pedagogical University

Hurskiy I. Yu.

Pavlo Tychyna Uman State Pedagogical University

\title{
FUNCTIONING OF STYLISTIC DEVICES IN THE POLITICAL SPEECHES OF AMERICAN EXPRESIDENT BARACK OBAMA
}

\begin{abstract}
A detailed study of linguistic features of political texts allows one to track the trends in linguistic changes and identify the linguistic means of modelling a communicative portrait of politicians in the light of dynamic challenges of the period in question. At the same time, it is essential to characterize their political discourse to investigate their political reality. Political speech acts as a form of public speaking, a communication process and a type of social action. One of the key figures is Barack Hussein Obama, an American politician and the 44th President of the United States. This linguistic research aims to describe the functioning of stylistic devices in his political speeches delivered in the period from June 1 to July 13, 2015, and, in particular, reveal the stylistic effect they create. The procedures and methods implemented during the research compile with the aim, objectives and the material analyzed. They include both general scientific methods and those related to linguistic research. The research shows that the great variety of stylistic devices used in the political texts in question mostly includes epithets (to create a portrait of a certain person); antitheses (to demonstrate contradictions); hyperboles (to express sincere feelings); metaphors (to create symbolic images, address the audience, cultivate an atmosphere of a communicative situation); anaphors (to enhance the characteristics of the image, emphasize and encourage the audience to analyze what is heard); simile (to emphasize a certain quality); repetition (to enable full-fledged image-creation and express the authority category). Thus, the stylistic devices identified during the linguistic analysis make it possible to convey the key ideas of the speech and serve as powerful means of implementing the tasks set by the politician. It is concluded that the genre of political speech serves as a powerful lever of linguistic influence on representatives of different social strata, because ideas masked in it by stylistic devices allow politicians to form a favorable image and manipulate public consciousness in a particular linguistic space.
\end{abstract}

Key words: political linguistics, political text, political leader, stylistic devices, functions, stylistic effect.

Introduction. The politicization of society is becoming a decisive area in its way towards globalization. The outlined social realities urge today's political linguistics to study political culture, thought and behaviour of society members. An increasing interest in the study of political texts lies in their linguistic reconsideration of the political discourse of the politicians who embody the people of the whole nation.

Analysis of recent research and publications. One of such key figures is Barack Hussein Obama, the $44^{\text {th }}$ President of the United States. His political speeches in the linguistic and stylistic context were studied by V. Bezrukov, O. Chorna, O. Dobosh, A. Dynnik, I. Hrohodza, O. Medvedieva, A. Pavliuk, I. Pasichnyk, O. Shcherbakova, N. Spitsyna, M. Tkhor, O. Yailokhanova, Yu. Zablotskyi, S. Zhabotynska et al.
In this regard, the growing importance of the communicative component of the political leader's image actualizes linguistic research on political speech as a genre, which highlights linguistic influence on representatives of different social groups. After all, the ideas "disguised" in it with the help of stylistic devices allow politicians to create a favourable image and manipulate public consciousness in a certain linguistic space.

Setting the goals and tasks of the article. This article aims to describe the functioning of stylistic devices in political speeches delivered by Barack Obama in the period from June 1 to July 13, 2015, and, in particular, reveal the stylistic effect they create.

Research procedures and methods agree with the aim, objectives and the material analyzed. They include both general scientific methods (analysis, 
synthesis, induction, deduction) and those related to linguistic research. In particular, the article employs the descriptive research method based on classification and systematization, as well as component-oriented and contextual methods of stylistic analysis.

The outline of the main research material. The research shows that the great variety of stylistic devices used in political texts in question includes epithets. It is essential to analyze how they function in different structural elements of the politician's speeches.

Beau Biden was an original. He was a good man. A man of character [1].

The given fragment allows one to analyze the inverted epithet "a man of character" which the speaker uses to model the portrait of the deceased, which is characteristic of eulogy. With this in mind, the listeners fall under the impression that the deceased had an original, good, strong personality.

One can also observe the use of antithesis in the analyzed speeches. For example: Sometimes cruelty is deliberate - the action of bullies or bigots, or the inaction of those indifferent to another's pain (1). In this sentence, Obama seeks to present cruelty in light of the contradictions created by the antithesis.

To suffer such faceless, seemingly random cruelty can harden the softest hearts, or shrink the sturdiest. It can make one mean, or bitter, or full of self-pity. Or, to paraphrase an old proverb, it can make you beg for a lighter burden [1].

In this fragment, one should consider such hyperbolized expressions as "harden the softest hearts", "shrink the sturdiest", "make you beg for a lighter burden". At the same time, their nonaccidental use enables one to create the image of cruelty endowed with the qualities of a human being, capable of transforming human feelings and causing the destruction of the human soul "captured by its powerful force". Barack Obama turns to the image of cruelty to express sincere feelings about the death of the person.

It is also important to focus on metaphorical expressions in Obama's speeches, such as "a cruel twist of fate" in the given micro context: For Beau, a cruel twist of fate came early - the car accident that took his mom and his sister, and confined Beau and Hunter, then still toddlers, to hospital beds at Christmastime [1].

Analyzing the function of this phrase, one should note that it acts as a collective concept and personifies the disaster that befell the government official's family. The use of the lexeme "cruel" is not accidental since it both indicates the negative side of things and discloses the image of cruelty in the analyzed eulogy.

And so, rather than use his childhood trauma as justification for a life of self-pity or self-centeredness, that very young boy made a very grown-up decision: He would live a life of meaning. He would live a life for others. He would ask God for broader shoulders [1].

Regarding this fragment, the key is the metaphorical expression "a very grown-up decision", which acquires a symbolic meaning in the description of childhood by the speaker. Moreover, the reinforcing element "very" aims to focus the listeners' attention on various aspects of this decision with the help of anaphora (a life of meaning, a life for others).

Also noteworthy is the metaphorical expression "ask God for broader shoulders". It seeks to create the image of a brave, courageous man who moves forward no matter the obstacles.

It is also vital to analyze the next fragment:

Like his father, Beau did not have a mean bone in his body. The cruelty he'd endured in his life didn't make him hard, it made him compassionate, empathetic. But it did make him abhor bullies [1].

Thus, Obama resorts to the use of the image of cruelty. Besides, the politician notes that the cruelty did not destroy the "compassionate" side of his soul.

Beau's grandfather, Joe's father, believed that the most egregious sin was to abuse your power to inflict pain on another. So, Beau squared his broad shoulders to protect people from that kind of abuse. He fought for homeowners who were cheated, seniors who were scammed. He even went after bullying itself. He set up a Child Protector - Predator Task Force, convicted more than 200 of those who targeted vulnerable children. And in all this, he did it in a way that was alive to the suffering of others, bringing in experts to help spare both the children and their parents further trauma.

That's who Beau was. Someone who cared. Someone who charmed you, and disarmed you, and put you at ease. When he'd have to attend a fancy fundraiser with people who took themselves way too seriously, he'd walk over to you and whisper something wildly inappropriate in your ear. The son of a senator, a Major in the Army, the most popular elected official in Delaware - I'm sorry, Joe - but he was not above dancing in nothing but a sombrero and shorts at Thanksgiving if it would shake loose a laugh from the people he loved.

And through it all, he was the consummate public servant, a notebook in his back pocket at all times so he could write down the problems of everyone he met and go back to the office to get them fixed [1]. 
Concerning this fragment, the use of the metaphor "broad shoulders" aims to create the image of compassion, sensitivity to others:

So, Beau squared his broad shoulders to protect people from that kind of abuse. He fought for homeowners who were cheated, seniors who were scammed. He even went after bullying itself [1].

It becomes obvious that compassion and nobility manifested in the fact that the hero acted as an opponent of the image. Interestingly, the speaker resorts to the use of anaphora to enhance the image in the second paragraph:

That's who Beau was. Someone who cared. Someone who charmed you, and disarmed you, and put you at ease [1].

One might think that the use of anaphora is the key to a perfect portrait of the hero. Indeed, it is not only a way to reinforce but also to "engrave" in the memory of people the hero that Obama himself remembered.

It is also important to trace how the metaphorical expression "make a name" functions in the context of the speech:

You know, anyone can make a name for themselves in this reality $T V$ age, especially in today's politics. If you're loud enough or controversial enough, you can get some attention.

But to make that name mean something, to have it associated with dignity and integrity - that is rare. There's no shortcut to get it. It's not something you can buy. But if you do right by your children, maybe you can pass it on. And what greater inheritance is there?

What greater inheritance than to be part of a family that passes on the values of what it means to be a great parent; that passes on the values of what it means to be a true citizen; that passes on the values of what it means to give back, fully and freely, without expecting anything in return? [1].

This particular metaphorical expression acquires the meaning of "becoming famous". It allows one to raise the topic of fame, purpose and create a positive impression of the deceased, a man who achieved everything he could have hoped. The stylistic richness of this eulogy makes it possible to look at another person's life from a new angle and in a different light.

That's what our country was built on - men like Beau. That's who built it-families like this. We don't have kings or queens or lords. We don't have to be born into money to have an impact. We don't have to step on one another to be successful. We have this remarkable privilege of being able to earn what we get out of life, with the knowledge that we are no higher than anybody else, or lower than anybody else. We know this not just because it is in our founding documents, but because families like the Bidens have made it so, because people like Beau have made it so.

$\mathrm{He}$ did in 46 years what most of us couldn't do in 146. He left nothing in the tank. He was a man who led a life where the means were as important as the ends. And the example he set made you want to be a better dad, or a better son, or a better brother or sister, better at your job, the better soldier. He made you want to be a better person. Isn't that finally the measure of a man - the way he lives, how he treats others, no matter what life may throw at him? [1].

In this regard, the fragment contains a generalizing subtext, owing to the fact that the simile in the sentence "That's what our country was built on - men like Beau" aims to emphasize a certain quality. Obama seeks to convey to the listeners that the deceased man largely contributed to the development of the country. Moreover, the politician argues that material values are not the main thing in life. In his opinion, the main thing is persistence. One cannot ignore the following sentence: He did in 46 years what most of us couldn't do in 146. He left nothing in the tank [1].

The numerals, which perform an emphasizing function in this micro context, allow Obama to highlight the man's achievements, despite his rather young age (46 years old). Still, the desire to express contrast also has an instructive meaning, that is to stimulate the listeners to rethink their lives and do as much as possible.

It must be noted that Barack Obama successfully manages to play the meaning of the adjective "better" in the context of his speech:

And the example he set made you want to be a better dad, or a better son, or a better brother or sister, better at your job, the better soldier. He made you want to be a better person. Isn't that finally the measure of a man - the way he lives, how he treats others, no matter what life may throw at him? [1].

Thus, the appeal to repetition in the speech is the "key" to full-fledged image-creation. Before that, the speaker speaks about the example and manages to achieve the planned stylistic effect through the prism of combining an adjective and a noun. In the context of the speech, such combinations are "a better dad", "a better son", "a better brother or sister", "better at your job", "the better soldier".

It is also expedient to analyze the following fragment:

We do not know how long we've got here. We don't know when fate will intervene. We cannot discern God's plan. What we do know is that with every minute that we've got, we can live our lives in a way that takes nothing for granted. 
We can love deeply. We can help people who need help. We can teach our children what matters, and pass on empathy and compassion and selflessness. We can teach them to have broad shoulders.

The use of anaphora, which performs an imagecreating (emphasizing) function, is quite noticeable. Emphasis acts as a turning point through the prism of creating a positive image.

One should also pay specific attention to the following sentences:

We can love deeply.

We can help people who need help.

We can teach our children what matters, and pass on empathy and compassion and selflessness.

We can teach them to have broad shoulders [1].

The emphasizing part in the given fragment is aimed at addressing the audience, as well as stimulating the analysis of what is heard.

To Joe and Jill - just like everybody else here, Michelle and I thank God you are in our lives.

Taking this ride with you is one of the great pleasures of our lives. Joe, you are my brother.

And I'm grateful every day that you've got such a big heart, and a big soul, and those broad shoulders. I couldn't admire you more.

I got to know Joe's mom, Catherine Eugenia Finnegan Biden, before she passed away. She was on stage with us when we were first elected. And I know she told Joe once that out of everything bad that happens to you, something good will come if you look hard enough.

And I suppose she was channeling that same Irish poet with whom I began today, Patrick Kavanagh, when he wrote, "And I said, let grief be a fallen leaf at the dawning of the day [1].

Analyzing this fragment, one cannot fail to notice that the adjective "big" acquires metaphorical meaning (a big heart; a big soul). Their meanings are consistent since they express the concept of "compassion". Consequently, one creates the image of a courageous and generous man in combination with the metaphor "broad shoulders".

In the context of the speech, the expression "let grief be a fallen leaf at the dawning of the day", which performs a stimulating function (the audience's appeal to reflection), is qualitatively distinguished.

As hard as it is right now, through all the heartache and through all the tears, it is our obligation to Beau to think not about what was and what might have been, but instead to think about what is, because of him.

Think about the day that dawns for children who are safer because of Beau, whose lives are fuller, because of him. Think about the day that dawns for parents who rest easier, and families who are freer, because of him. Some folks may never know that their lives are better because of Beau Biden. But that's okay.

Certainly for Beau, acclaim was never the point of public service [1].

The first paragraph of the fragment is characterized by the stylistic richness, which reflects the grief and sadness of the speaker:

But the lines of well-wishers who've been here all week - they know. The White House mailroom that's been overflowing with letters from people - those folks know.

The soldiers who served with Beau, who joined the National Guard because of him. The workers at Verdi's who still have their home because of him, and who thanked him for helping them bus tables one busy night. The students in Newark who remember the time he talked with them for hours, inexhaustible, even after giving a speech, even after taking his National Guard fitness test. The Rehoboth woman who's saved a kind voicemail from him for five years, and wrote to say "I loved the way he loved his family". And the stranger who wrote from halfway across this great country just to say, "The only thing we can hope for is that our children make us proud by making a difference in the world. Beau has done that and then some. The world noticed" [2].

In this fragment, the speaker addresses the listeners:

"Through our great good fortune, in our youth our hearts were touched with fire", said Oliver Wendell Holmes, Jr. "But, above all, we have learned that whether a man accepts from Fortune her spade, and will look downward and dig, or from Aspiration her axe and cord, and will scale the ice, the one and only success which it is his to command is to bring to his work a mighty heart".

At the same time, he uses the metaphors "our hearts were touched with fire" and "a mighty heart". The metaphor also plays an important role in creating an atmosphere of the communicative situation. For example: May God bless his memory, and the lives of all he touched [1]. Metaphorical turns are designed to create a positive image in the context of the speech.

The analyzed speeches also include the appeal to the text of a literary work with a specific stylistic purpose. Here is the following fragment:

He said they lived meaningful lives, and they died nobly. "They say to each of us", Dr. King said:

$\langle\ldots>$ black and white alike, that we must substitute courage for caution. They say to us that 
we must be concerned not merely with [about] who murdered them, but about the system, the way of life, the philosophy which produced the murderers.

Their death says to us that we must work passionately and unrelentingly for the realization of the American Dream.

And if one will hold on, he will discover that God walks with him, and that God is able to lift you from the fatigue of despair to the buoyancy of hope, and transform dark and desolate valleys into sunlit paths of inner peace.

It is also necessary to analyze the following fragment:

And ultimately, Congress acts when the public insists on action. And we've seen how public opinion can change. We've seen it change on gay marriage. We've seen it beginning to change on climate change. We've got to shift how we think about this issue. And we have the capacity to change, but we have to feel a sense of urgency about it. We, as a people, have got to change. That's how we honor those families. That's how we honor the families in Newtown. That's how we honor the families in Aurora.

The metaphorical expression "the public insists on action" conveys the condition under which Congress will function.

Below are anaphoric beginnings:

And we've seen how public opinion can change.

We've seen it change on gay marriage.

We've seen it beginning to change on climate change.

We've got to shift how we think about this issue.

The analyzed example indicates that anaphora is intended to define the range of past actions.
I've been clear, I will not sign bills at sequestration levels. I will not sign bills that seek to increase defense spending before addressing any of our needs here at home.

And I need your help. I need your help, Mayors, to talk to your members of Congress to get rid of the sequester once and for all - because it is harming our cities and harming our country. There is no business - no successful business - that if it needed to reduce spending, would simply lop off 10 percent of everything. Or 15 percent of everything.

That's not how any of us would run our household budget. You'd cut out things you don't need, but you'd still keep the college fund going. You'd still pay your health insurance bill and your mortgage note. There are things we have to do as a country to stay ahead [2].

The analysis of the mentioned fragment shows that repetition of the first and second sentences in the second paragraph of the speech serves as the result of expressing the authority category which should be understood as the exercise of linguistic influence by government officials on various social groups.

Conclusions. Thus, this research proves that the analyzed stylistic devices (epithets, metaphors, simile, anaphora, stylistic repetition, hyperbole) used in political speeches of Barack Obama make it possible to convey the key ideas of the speech and serve as powerful means of implementing the tasks set by the politician. However, it does not disclose all aspects of political speech as a genre in general and speeches by Barack Obama in particular. Therefore, further research should be aimed at the following areas: the structural organization of Barack Obama's political speeches; speechwriting technology as an integral part of political communication.

\section{References:}

2. Address to U. S. Conference of Mayors [Electronic resource]. URL: https://www.americanrhetoric.com/ speeches/barackobama/barackobamamayorsconference2015.htm.

3. Eulogy for Beau Biden III [Electronic resource]. URL: https://www.americanrhetoric.com/speeches/ barackobama/barackobamabeaubideneulogy.htm.

4. Тхір М. Прагматичний ефект стилістичних засобів у політичних промовах президента США Барака Обами. Мова і культура. 2015. Вип. 18. Т. 2. С. 62-69.

5. Чорна О. Комунікативний імідж сучасного американського політика: парадигма ролей (на матеріалі промов Барака Обами). Наукові записки Кіровоградського державного педагогічного університету імені Володимира Винниченка. Серія «Філологічні науки». 2010. Вип. 89 (5). С. 375-379.

6. Шакова Б. Различные подходы к исследованию политического дискурса. Филологические науки. Вопросы теории и практики. 2013. № 9 (27) : в 2-х ч. Ч. 1. С. 195-198.

\section{Білецька І. О., ГУрськИй І. Ю. ФУНКЦІОНУВАННЯ СТИЛІСТИЧНИХ ЗАСОБІВ У ПОЛІТИЧНИХ ПРОМОВАХ АМЕРИКАНСЬКОГО ЕКСПРЕЗИДЕНТА БАРАКА ОБАМИ}

Детальне вивчення лінгвістичних особливостей політичних текстів уможливлює відстеження тенденцій мовних змін, окреслення лінгвістичних засобів моделювання комунікативного портрета політика у світлі динамічних викликів досліджуваного періоду. Для комплексного вивчення політичної 
реальності, яка моделюється окремим політиком, важливим є звернення до його політичного дискурсу. Політична промова є формою публічного виступу, прочесом комунікації й одним із видів соціальної дії. Однією із ключових постатей є американський політик, 44-й президент Сполучених Штатів Америки - Барак Хусейн Обама. У фокусі наших лінгвістичних пошуків - дослідження особливостей функиіонування стилістичних засобів у його політичних промовах, виголошених у період з 1 червня по 13 липня 2015 року, зокрема зазначити стилістичний ефект, який вони створюють. Процедури та методи, зреалізовані під час дослідження, визначаються метою, завданнями та матеріалом, що аналізувався. Вони включають як загальнонаукові методи, так і ті, щзо стосуються власне лінгвістичного дослідження. Дослідження показало, шео серед великого розмаїття стилістичних засобів у проаналізованих нами політичних текстах, виголочених американським ексочільником Сполучених Штатів Америки, були виявлені випадки широкого вживання епітетів (з метою моделювання портрета певної особи); антитези (з метою демонстрації суперечностей); гіперболи (з метою висловлення щирих почуттів); метафори (з метою моделювання символічних образів, звернення аудиторії до роздумів, створення атмосфери комунікативної ситуачії); анафори (для підсилення характеристики образу, наголошення, стимулювання до аналізу почутого); порівняння (для створення такого стилістичного ефекту, як наголочення на окремій якості); повторів (з метою повночінного образотворення, вираження категорії авторитетності). Отже, виокремлені у процесі лінгвістичного аналізу стилістичні засоби уможливлюють донесення ключових ідей виступу, маніпулювання суспільною свідомістю в певному лінгвістичному просторі та є потужними засобами формування сприятливого іміджу і реалізаиії поставлених політиком завдань.

Ключові слова: політична лінгвістика, політичний текст, політичний лідер, стилістичні засоби, функиії, стилістичний ефект. 